\title{
An Analysis of the Current Situation and Countermeasures of Innovative Entrepreneurship Education in Agricultural Colleges and Universities
}

\author{
Chao Wang ${ }^{1, a}$ and Junzheng Wang ${ }^{2, b}$ * \\ ${ }^{1,2}$ Xincheng Street 2888, Jilin Agricultural University, Changchun, Jilin Province 130118, PR China \\ a29251275@qq.com,b595845966@qq.com \\ ${ }^{*}$ The Corresponding author
}

\begin{abstract}
Keywords: Higher agricultural colleges; Innovation and entrepreneurship education; Status situation and countermeasures
\end{abstract}

\begin{abstract}
At present, the state to implement the relevant policies to encourage the "public entrepreneurship, innovation", combined with this background, this article from the concept of unclear, too much emphasis on innovation; not yet formed a sound innovative entrepreneurial curriculum system; lack of various forms of innovation and entrepreneurship Practice platform; innovative business environment to be improved and so on the analysis of higher vocational colleges innovation entrepreneurial team status quo. And put forward the improvement measures of changing the educational concept, re-process and cultivating the ability; establishing and perfecting the innovation and entrepreneurship course system and perfecting the government and the university's entrepreneurial guarantee mechanism.
\end{abstract}

\section{The Status Situation and Problems of Innovation and Entrepreneurship Education in Higher Agricultural Colleges}

Lack of Understanding of the Concept, Too Much Emphasis on the Results of Innovative Entrepreneurship Education. The local higher agricultural institutions to know more about innovation and entrepreneurship education still stay in support of college students innovation and entrepreneurship of the typical individuals and groups, will be more innovative business resources concentrated in a small number of outstanding entrepreneurs and individuals in the group, the concept of understanding Clear, more one-sided [1]. School of this approach is to understand the innovative entrepreneurship education as "elite education", contrary to the country to promote innovation and entrepreneurship "popular education."

Has Not Yet Formed a Sound Innovative Entrepreneurial Curriculum System. Most of the institutions of higher agricultural colleges lack the scientific and rational innovation and entrepreneurship curriculum system, the establishment of innovative entrepreneurship courses are generally in college career planning and employment guidance and other elective courses, not organized professional innovation and entrepreneurship courses. In addition, the curriculum of colleges and universities is still in the form of classroom teaching and practice courses combined. College curriculum to set up a professional knowledge-based teaching, curriculum arrangements, students learning tasks, and no more time to elect the school set up innovative business courses elective courses. In addition, the innovation and entrepreneurship courses as an elective course, its curriculum management, course time and curriculum focus on the degree of attention can not be well protected. This is not conducive to attract the majority of students interest in innovation and entrepreneurship and training students the ability to innovate and start.

Weak Educational Foundation, Lack of Professional Teacher Guidance Team. Specialized teachers in higher agricultural colleges have some professional knowledge and neglected practical experience and innovative knowledge of entrepreneurship. Many of the agricultural institutions of teachers lack of enterprises and institutions to participate in the practice of training experience, failed to timely according to the market demand for talent changes in time to update their teaching direction and teaching content. In addition, the teachers of agricultural institutions because of the main agricultural projects for scientific research, and political relations is not strong, the lack of the 
latest innovative business news and awareness. In the specific professional teaching, failed to professional knowledge and innovative business information, the organic combination of students to pass. In addition, the college innovation and entrepreneurship teachers generally by the counselor teacher, counselor teacher's work intensity is very difficult, it is difficult to have more time and try to innovate students to give efficient and professional guidance [2].

Weak Innovation and Entrepreneurial Practice Platform, Innovation and Innovation Results. At present, many high agricultural colleges and universities in the form of innovative business platform, only a small number of innovative entrepreneurship laboratory and college students innovation and technology park and other practical platform. The school's innovative business courses are limited to the same school, with the professional, ignoring the interdisciplinary, interdisciplinary innovation and entrepreneurship courses founded. Innovation and entrepreneurial achievements and achievements failed to link with the student's talent training system. At the same time, between the school level has not established an innovative business resource sharing platform. Innovative business activities between colleges and universities are their own fight, the lack of cooperation and exchanges. In addition, the higher agricultural institutions have too much emphasis on the research and development of agricultural innovation and entrepreneurship projects, while ignoring the students in the process of innovation and entrepreneurship, practical ability, management ability and coordination ability and so on.

\section{The Reform of Innovative Agricultural Education in Higher Agricultural Colleges and Universities}

Change the Concept of Education, Attention to Innovation and Entrepreneurship Ability Training Process. First, the higher agricultural institutions to change the concept of education, refused to change the innovation and entrepreneurship "elite education" as "popular education" to encourage students interested in active innovation, institutions to carry out innovation and entrepreneurship students to provide funds, teacher guidance And other resources to help expand the school innovation and entrepreneurship boom. Second, the school also need to change the one-sided attention to innovation and entrepreneurship results, ignoring the process of innovation and entrepreneurship ability of students. Innovation and entrepreneurship education emphasis on the development of student capacity, the formation of professional knowledge-based, skills training as a platform to build students innovative entrepreneurial knowledge system and the development of students innovative entrepreneurial ability.

To Establish a Sound Innovation and Entrepreneurship Curriculum System. The aim of innovation and entrepreneurship education in higher agricultural colleges is to improve the comprehensive quality of students' innovation and entrepreneurship. With the increasing demand of talents in the market, the cultivation of talents will inevitably involve interdisciplinary integration. In addition, we should also create a combination of professional knowledge education and general education education system of innovative entrepreneurship education system [3]; creative thinking, cutting frontier information, business foundation, legal and management knowledge combined with innovative entrepreneurial curriculum theory courses; Through the development of school-based curriculum, with the micro-class, Mooc and other modern teaching techniques will be combined for students to show the region's rich agricultural characteristics of innovative business practice case, to develop students to carry out practical and innovative entrepreneurial project capabilities.

\section{To Strengthen the Innovation and Entrepreneurship Team Building.}

A. Establishment of Comprehensive Innovation Department of Higher Agricultural Institutions

In the university, according to the teacher's age, education and ability to form a structured and reasonable, theoretical knowledge and practical experience of innovative entrepreneurship instructors, and the establishment of theoretical integrated departments. To facilitate the innovation and entrepreneurship teachers to keep abreast of innovation and entrepreneurship education at home and abroad the latest developments and theoretical frontiers, master the Central No. 1 document to 
understand the country's agricultural policy trends, grasp the country on innovation and entrepreneurship education the latest macroeconomic policy, accurate and timely to determine the higher The specific direction of the innovation and entrepreneurship of agricultural colleges and the establishment of scientific research team.

B. The establishment of innovation and entrepreneurship teacher development center

The department is mainly responsible for the innovation and entrepreneurship of the instructor to carry out vocational qualification certification, for the innovation and entrepreneurship instructors to provide relevant training, academic salons, corporate training and other forms of full vocational qualification certification, and constantly expand the teacher guidance team. At the same time, by hiring well-known entrepreneurs, experts and scholars and creative entrepreneurship professional, business management personnel and other talents into the campus, organized for innovative entrepreneurs to carry out various forms of academic exchanges [4]. Encourage innovation and entrepreneurship teachers to enter the relevant enterprises and institutions to carry out the training, and constantly expand the practical experience of teachers to facilitate innovation and entrepreneurship will be theoretical knowledge and practical knowledge combined to prepare for the training of innovative entrepreneurship. Therefore, the formation of a school of professional entrepreneurship entrepreneurship-led, entrepreneurs and other innovative entrepreneurs to help the success of teachers to guide the team is to ensure the success of students innovation and success of an important guarantee.

The Establishment of a Variety of Innovative Business Practice Platform. Innovative business practice platform should be a variety of forms, should not be confined to the curriculum platform and practice platform, but also should be extended to the innovative business competition platform, science and technology innovation platform and other forms. In the platform of the platform to set up interdisciplinary, cross-disciplinary innovation and entrepreneurship training courses; in the practice platform to deal with innovation and entrepreneurship practice results and the relationship between student training programs in the competition platform to set up a good school Innovation and entrepreneurial activities of the resource sharing and cooperation and exchange, at the same time through a variety of incentives to encourage students to actively participate in innovation and entrepreneurship activities; in the platform of scientific and technological innovation, the school and the government, enterprises to establish innovative business safety mechanism, the school duty-free government, Financing and other aspects of the policy to protect the organization of innovative entrepreneurship learning and understanding, social enterprises should provide students with a practical platform to encourage students to start business in the entrepreneurial entrepreneurial project internship, through the successful development of innovative business projects that can help enterprises to break through technical difficulties, but also to enrich the practical experience of students.

\section{Conclusion}

In view of the current high-level agricultural institutions innovation and entrepreneurship concept is unclear, has not yet formed a perfect entrepreneurial curriculum system and teachers are not complete and other issues, the implementation of a sound innovative entrepreneurial curriculum system to build a variety of forms of innovative business practice platform reform measures for the cultivation of students innovation and entrepreneurship has an important role.

\section{Acknowledgements}

2016 Jilin Agricultural University school-based special subject: "Jilin Agricultural University innovative talent training system" (project number: 2016XSZX02) 


\section{References}

[1] Wu Lu-guang, Liu Hao.Study and exploration of innovation and entrepreneurship education in local higher agricultural colleges and universities [J]. Shanxi Agricultural Economics, 2016, (09): 30-32.

[2] Wang Xiangkai, Pan Yue, Zheng Shiyan. Problems and Countermeasures in College Students' Entrepreneurship Education - Based on the Analysis of Local Higher Agricultural Institutions [J]. Journal of Tianjin College of commerce, 2015, (05): 53-55 + 64

[3] Feng Xiao. Higher agricultural colleges and universities innovation and entrepreneurship education reform practice and exploration [J]. China Agricultural Education, 2015, (05): 1-7.

[4] Zhou Chuntao, Guan Jian. On the promotion of entrepreneurship education in local agricultural colleges and universities [J]. Journal of Changchun Institute of education, 2013, (01): 107-108 